\title{
The allele frequencies of three polymorphisms in genes involved in homocysteine metabolism in a group of unrelated healthy Singaporeans
}

\author{
Chuanfei Chen* and Yik-Yuen Gan \\ Natural Sciences and Science Education, National Institute of Education, Nanyang Technological University, \\ Singapore
}

\begin{abstract}
The cystathionine $\beta$-synthase (CBS) 844ins68 polymorphism, methionine synthase (MS) A2756G SNP, and 5,10methylenetetrahydrofolate reductase (MTHFR) C677T SNP are associated with homocysteine (Hcy) level in humans. Elevated Hcy level is considered a risk factor for atherosclerotic diseases among Asian populations. Therefore, the three polymorphisms may vary the risk for developing such diseases in Singaporeans. In this study, the three polymorphisms were determined in a group of unrelated healthy Singaporeans (273 Chinese, 127 Indians, and 156 Malays). Regarding allele frequencies, Indians had the highest frequencies of the $C B S$ insertion allele (2.0\%) and the $M S 2756 \mathrm{G}$ allele (26.4\%), while Chinese had the highest MTHFR 677T allele frequency (27.5\%). In addition, the MTHFR 677T allele was found significantly lower in Chinese males than in their female counterparts. As the $C B S$ insertion allele was suggested to be associated with lower Hcy level, whereas the $M S$ $2756 \mathrm{G}$ allele and the MTHFR T/T genotype were related to higher Hcy level, the $M S \mathrm{~A} / \mathrm{G}$ or G/G genotype and the $M T H F R$ T/T genotype were considered double genetic risk factors for elevated Hcy level. The frequency of such double genetic risk was $0.7 \%$ (4 subjects) in the total population consisting of 3 Chinese (1.1\%) and 1 Malays $(0.6 \%)$. No MTHFR T/T genotype was found in Indians. Such results suggested that Chinese could have higher Hcy levels than Malays while the situation for Indians was complicated. Since human Hcy levels are also affected by environmental factors, further studies are required to better evaluate the association between these three polymorphisms and Hcy levels and/or disease susceptibilities in Singaporeans.
\end{abstract}

Keywords: Cystathionine $\beta$-synthase, Methionine synthase, 5,10-Methylenetetrahydrofolate reductase, Polymorphism, Homocysteine, Singaporean

\section{Introduction}

Homocysteine is a sulfydryl-containing amino acid derived from the metabolic demethylation of dietary methionine. In humans, Hcy can either be converted to cystathionine by the enzyme cystathionine $\beta$-synthase (CBS) (the transulfuration pathway), or it can be methylated to form methionine by the enzyme methion-

\footnotetext{
* Corresponding author: Mr. Chuanfei Chen, BLK 663A, \#14-295, Jurong West Street 65, 641663, Singapore. Tel.: +65 67925170; E-mail: twinfere@gmail.com.
}

ine synthase (MS) (the remethylation pathway), using 5-methyltetrahydrofolate as a methyl donor, which is converted from 5,10-methylenetetrahydrofolate by the enzyme 5,10-methylenetetrahydrofolate reductase (MTHFR) [1].

Since CBS, MS, and MTHFR are all involved in the conversion of Hcy to other metabolites, polymorphisms located on these genes have been extensively studied and some of them are found associated with varied levels of plasma Hcy. At the $C B S$ gene, a 68-bp insertion between base 844 and 845 (844ins68) at the junction of intron 7 and exon 8 has been associated with lower post-methionine load increase in total Hcy concentra- 
tions [2,3]. At the $M S$ gene, an A to $\mathrm{G}$ transition at nucleotide 2756 (A2756G), which results in the substitution of glycine for aspartic acid at amino acid position 919 (D919G), has been described [4]. In Indian [5] and Korean [6] populations, the $2756 \mathrm{G}$ allele was found to be associated with increased Hcy levels. Finally at the MTHFR gene, a common $\mathrm{C}$ to $\mathrm{T}$ transition at nucleotide 677 (C677T), which leads to the substitution of valine for alanine, has been reported to impair the enzymatic activity of MTHFR [7], and the homozygous form of the $677 \mathrm{~T}$ allele (T/T genotype) is therefore associated with higher Hcy concentrations than the other two genotypes among major Asian populations including Japanese [8,9], Koreans [6], and Chinese [10,11].

Among Asian populations, elevated tHcy level has been suggested to relate to some atherosclerotic diseases, such as cardiovascular disease (CVD) in Indians [12] and Chinese [13] and coronary artery disease (CAD) in Taiwanese Chinese [14,15], as well as to thrombotic disease, i.e., venous thromboembolism in Taiwanese Chinese [16]. In this sense, screening the aforementioned three polymorphisms among general populations may help to define the possible genetic risk factors that affect the susceptibility to these diseases. The objectives of the present study are to: (1) determine the allele frequency of the three polymorphisms, namely, the CBS 844ins68 polymorphism, the MS A2756G SNP, and the MTHFR C677T SNP, in unrelated healthy individuals of Singaporean Chinese, Indians, and Malays; and (2) evaluate the carriage rate of multiple genetic risk factors for elevated Hcy concentrations among Singaporeans.

\section{Materials and methods}

\subsection{Experimental subjects}

A total of 556 unrelated Singaporeans (273 Chinese, 127 Indians, and 156 Malays) were enrolled. They were apparently healthy and not on medication by selfindication. The majority of participants were polytechnic and college students and trainee teachers. The average age (Mean \pm S.D.) of the three ethnic groups were $27.6 \pm 9.7 \mathrm{yr}$ ( 17 to $71 \mathrm{yr}$ ) for Chinese, $31.0 \pm 10.7$ (15 to $60 \mathrm{yr}$ ) for Indians, and $29.4 \pm 13.5$ (15 to $68 \mathrm{yr}$ ) for Malays. Written informed consents for DNA analysis were obtained from all participants and the study was approved by the local ethics committee.

\subsection{Genomic DNA extraction}

Genomic DNA was isolated from buccal cells. Briefly, each participant vigorously swished $10 \mathrm{ml}$ of sterile saline solution for $30 \mathrm{~s}$ after rinsing his/her mouth with water. One milliliter of the solution was centrifuged at room temperature $(13,000 \mathrm{rpm}, 2 \mathrm{~min})$. The buccal cell pellet was re-suspended in $50 \mu \mathrm{l}$ of saline solution and then transferred into $100 \mu \mathrm{l}$ of $10 \%$ (w/v) Chelex (Bio-Rad, Hercules, CA, USA) solution (1 $\mathrm{g}$ of Chelex $100 \mathrm{in} 10 \mathrm{ml}$ of $50 \mathrm{mM}$ Tris; pH 11). The Chelex solution with buccal cells was heated to $99^{\circ} \mathrm{C}$ for $10 \mathrm{~min}$ before it was centrifuged at room temperature (13,000 rpm, $2 \mathrm{~min})$. After centrifuge, $100 \mu \mathrm{l}$ of the supernatant, containing the genomic DNA from buccal cells, was collected and stored at $-20^{\circ} \mathrm{C}$ for later use.

\subsection{Genotyping}

The $C B S$ 844ins68 polymorphism was genotyped by PCR, while the $M S$ A2756G SNP and the MTHFR C677T SNP were genotyped by PCR-RFLP analysis. For all the three polymorphisms, PCR was carried out in a volume of $25 \mu \mathrm{l}$ containing $3 \mu \mathrm{l}$ of genomic DNA solution, $200 \mu \mathrm{M}$ of each dNTP, $1 \times$ ThermoPol Reaction Buffer $\left(10 \mathrm{mM} \mathrm{KCl}, 10 \mathrm{mM}\left(\mathrm{NH}_{4}\right)_{2} \mathrm{SO}_{4}, 20 \mathrm{mM}\right.$ Tris- $\mathrm{HCl}, 2 \mathrm{mM} \mathrm{MgSO}_{4}, 0.1 \%$ Triton X-100, $\mathrm{pH} 8.8$ ), $0.5 \mathrm{U}$ of Taq DNA polymerase (New England BioLabs, Ipswich, MA, USA) and 9 pmol of each primer (Research Biolabs, Singapore). Primer sequences, PCR cycle conditions, and size of products were summarized in Table 1. To detect the MS A2756G SNP, $5 \mu 1$ of PCR products were digested with 2 U of HaeIII restriction enzyme (New England BioLabs) in a $10 \mu \mathrm{l}$ reaction system at $37^{\circ} \mathrm{C}$ for $3 \mathrm{~h}$. For the detection of the MTHFR C677T SNP, $8 \mu \mathrm{l}$ of PCR products were digested with $1 \mathrm{U}$ of HinfI restriction enzyme (New England BioLabs) in a $16 \mu \mathrm{l}$ reaction system at $37^{\circ} \mathrm{C}$ for $3 \mathrm{~h}$. The products were electrophoresed in $2 \%(\mathrm{w} / \mathrm{v})$ agarose (Bio-Rad) gels and the bands were visualized by ethidium bromide staining.

\subsection{Data analysis}

Genotype and allele frequencies were determined by direct counting. Genotype frequencies of each ethnic group were tested for Hardy-Weinberg Equilibrium (HWE) using goodness-of-fit Chi-square test. HWE was assumed when $p>0.05$. Comparisons of genotypic and allelic distributions were done by Chi-square test using SPSS 11.0 for windows (SPSS Inc., Chicago, IL, USA). The differences was considered significant if $p \leqslant 0.05$. 
Table 1

Primer sequences, PCR cycle conditions and sizes of products for the genotyping of polymorphisms

\begin{tabular}{|c|c|c|c|c|c|c|c|}
\hline \multirow{2}{*}{$\begin{array}{l}\text { Gene } \\
C B S\end{array}$} & \multirow{2}{*}{$\begin{array}{l}\text { Primer sequence } \\
\text { 5'-GTTGTTAACGGCGGTATTGG-3' } \\
\text { 5'-GTTGTCTGCTCCGTCTGGTT-3' }\end{array}$} & \multicolumn{3}{|c|}{ PCR cycle condition } & \multirow{2}{*}{$\begin{array}{c}\begin{array}{c}\text { Restriction } \\
\text { enzyme }\end{array} \\
-\end{array}$} & \multicolumn{2}{|c|}{ Size of products } \\
\hline & & & $\begin{array}{l}94^{\circ} \mathrm{C} 30 \mathrm{~s} \\
58^{\circ} \mathrm{C} 40 \mathrm{~s} \\
72^{\circ} \mathrm{C} 60 \mathrm{~s} \\
35 \text { cycles }\end{array}$ & & & $\begin{array}{l}\mathrm{N} \text { allele }^{\mathrm{a}} \\
\text { I allele }\end{array}$ & $\begin{array}{l}240 \mathrm{bp} \\
172 \mathrm{bp}\end{array}$ \\
\hline$M S$ & $\begin{array}{l}\text { 5'-GGTGTGTTCCCAGCTGTTAGATG-3' } \\
\text { 5'-GACACTGAAGACCTCTGATTTGAAC-3' }\end{array}$ & $\begin{array}{l}94^{\circ} \mathrm{C} \\
10 \mathrm{~min}\end{array}$ & $\begin{array}{l}94^{\circ} \mathrm{C} 30 \mathrm{~s} \\
56^{\circ} \mathrm{C} 40 \mathrm{~s} \\
72^{\circ} \mathrm{C} 30 \mathrm{~s} \\
38 \text { cycles }\end{array}$ & $\begin{array}{l}72^{\circ} \mathrm{C} \\
10 \mathrm{~min}\end{array}$ & HaeIII & $\begin{array}{l}\text { A allele } \\
\text { G allele }\end{array}$ & $\begin{array}{c}265 \mathrm{bp} \\
180 \mathrm{bp}, 85 \mathrm{bp}\end{array}$ \\
\hline MTHFR & $\begin{array}{l}\text { 5'-TGAAGGAGAAGGTGTCTGCGGGA-3' } \\
\text { 5'-AGGACGGTGCGGTGAGAGTG-3' }\end{array}$ & & $\begin{array}{l}94^{\circ} \mathrm{C} 30 \mathrm{~s} \\
60^{\circ} \mathrm{C} 40 \mathrm{~s} \\
72^{\circ} \mathrm{C} 40 \mathrm{~s} \\
35 \text { cycles }\end{array}$ & & HinfI & $\begin{array}{l}\mathrm{C} \text { allele } \\
\mathrm{T} \text { allele }\end{array}$ & $\begin{array}{c}198 \mathrm{bp} \\
175 \mathrm{bp}, 23 \mathrm{bp}\end{array}$ \\
\hline
\end{tabular}

${ }^{\mathrm{a}}$ Non-insertion allele; ${ }^{\mathrm{b}}$ Insertion allele.

Table 2

Genotype frequencies, allele frequencies, and test for HWE

\begin{tabular}{ccccccc}
\hline Ethnic group & \multicolumn{2}{c}{ Genotype frequency $(\mathrm{n} / \%)$} & \multicolumn{2}{c}{ Allele frequency $(\mathrm{n} / \%)$} & Test for HWE \\
\hline$C B S$ & $\mathrm{~N} / \mathrm{N}$ & $\mathrm{I} / \mathrm{N}$ & $\mathrm{I} / \mathrm{I}$ & $\mathrm{I}$ & $\mathrm{N}$ & \\
Chinese & $271 / 99.3$ & $2 / 0.7^{\mathrm{a}}$ & 0 & $2 / 0.4^{\mathrm{b}}$ & $544 / 99.6$ & $p=0.995$ \\
Indians & $122 / 96.1$ & $5 / 3.9$ & 0 & $5 / 2.0$ & $249 / 98.0$ & $p=0.980$ \\
Malays & $151 / 96.8$ & $5 / 3.2$ & 0 & $5 / 1.6$ & $307 / 98.4$ & $p=0.985$ \\
MS & $\mathrm{A} / \mathrm{A}$ & $\mathrm{A} / \mathrm{G}$ & $\mathrm{G} / \mathrm{G}$ & $\mathrm{A}$ & $\mathrm{G}$ & \\
Chinese & $214 / 78.4$ & $58 / 21.2$ & $1 / 0.4^{\mathrm{c}}$ & $486 / 89.0$ & $60 / 11.0^{d}$ & $p=0.365$ \\
Indians & $73 / 57.5$ & $41 / 32.3$ & $13 / 10.2^{\mathrm{e}}$ & $187 / 73.6$ & $67 / 26.4^{\mathrm{f}}$ & $p=0.167$ \\
Malays & $106 / 67.9$ & $44 / 28.2$ & $6 / 3.8$ & $256 / 82.1$ & $56 / 17.9$ & $p=0.867$ \\
MTHFR & $\mathrm{C} / \mathrm{C}$ & $\mathrm{C} / \mathrm{T}$ & $\mathrm{T} / \mathrm{T}$ & $\mathrm{C}$ & $\mathrm{T}$ & \\
Chinese & $140 / 51.3$ & $116 / 42.5$ & $17 / 6.2^{\mathrm{g}}$ & $396 / 72.5$ & $150 / 27.5^{\mathrm{h}}$ & $p=0.550$ \\
Indians & $96 / 75.6$ & $31 / 24.4$ & 0 & $223 / 87.8$ & $31 / 12.2$ & $p=0.377$ \\
Malays & $125 / 80.1$ & $29 / 18.6$ & $2 / 1.3$ & $279 / 89.4$ & $33 / 10.6$ & $p=0.970$ \\
\hline
\end{tabular}

${ }^{\text {a }}$ The frequency of the $C B S$ I/N genotype is significantly lower in Chinese than in Indians $(p=$ $0.023)$.

${ }^{\mathrm{b}}$ The frequency of the $C B S$ I allele is significantly lower in Chinese than in Indians $(p=0.024)$.

${ }^{\mathrm{c}}$ The frequency of the $M S \mathrm{G} / \mathrm{G}$ genotype is significantly lower in Chinese than in Malays ( $p=$ 0.006).

${ }^{\mathrm{d}}$ The frequency of the $M S \mathrm{G}$ allele is significantly lower in Chinese than in Malays $(p=0.004)$.

e The frequency of the $M S \mathrm{G} / \mathrm{G}$ genotype is significantly higher in Indians than in Chinese ( $p=$ $0.000)$ and Malays $(p=0.033)$.

${ }^{\mathrm{f}}$ The frequency of the $M S \mathrm{G}$ allele is significantly higher in Indians than in Chinese $(p=0.000)$ and Malays $(p=0.016)$.

gThe frequency of the MTHFR T/T genotype is significantly higher in Chinese than in Indians $(p=0.004)$ and Malays $(p=0.017)$.

${ }^{\mathrm{h}}$ The frequency of the MTHFR $\mathrm{T}$ allele is significantly higher in Chinese than in Indians and Malays (both $p=0.000$ ).

\section{Results}

Genotype patterns of the three polymorphisms displayed by agarose gel electrophoresis were shown in Fig. 1. All the genotype frequencies were conforming to HWE (Table 2). As expected, there was no homozygous state of the insertion allele (I/I genotype) for the $C B S 844$ ins 68 polymorphism in the 556 individuals tested (Table 2). However, $0.7 \%$ of Chinese, $3.9 \%$ of Indians, and $3.2 \%$ of Malays were carriers of the I al- lele, resulting in I allele frequencies of $0.4 \%$ in Chinese, $2.0 \%$ in Indians, and $1.6 \%$ in Malays. Accordingly, the CBS 844ins68 is not a polymorphism to our Chinese samples since the frequency of the minor allele (I allele) does not reach $1 \%$ in this group. In addition, both of the frequencies of insertion/non-insertion (I/N) genotype and I allele were significantly lower in Chinese than in Indians ( $p=0.023$ and 0.024 , respectively).

The MS 2756G and MTHFR 677T alleles were common in all the three ethnic groups (Table 2). The fre- 

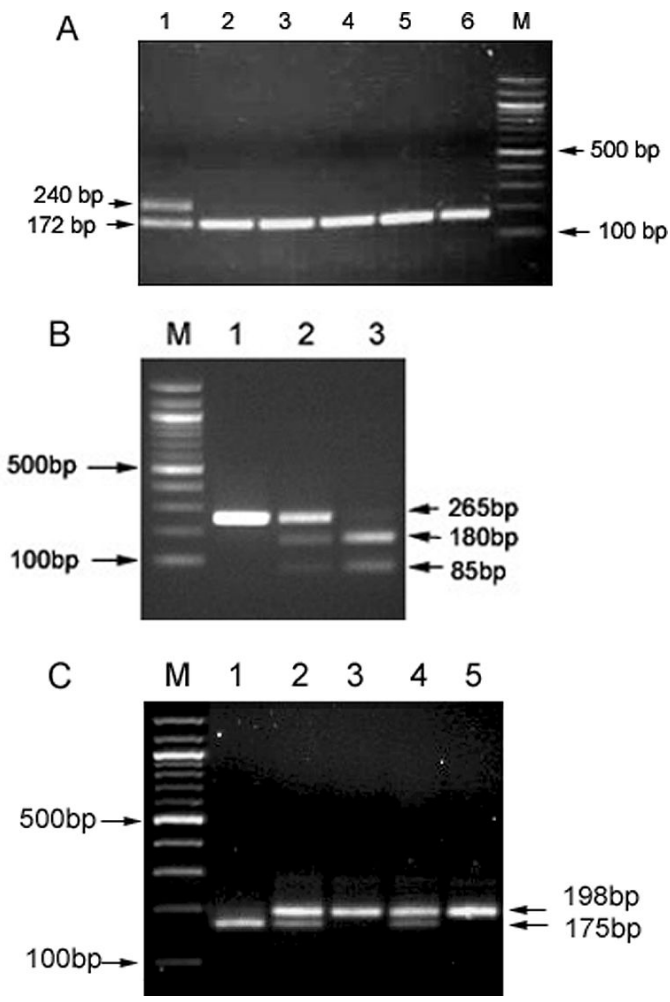

Fig. 1. Genotype patterns of the three polymorphisms displayed by agarose gel electrophoresis. M, 100 bp DNA ladder. (A) Genotype patterns of the CBS 844ins68 polymorphism. Lane 1, I/N genotype; lanes 2 to 6,N/N genotype. (B) Genotype patterns of the MS A2756G SNP. Lane 1, A/A genotype; lane 2, A/G genotype; and lane 3, G/G genotype. (C) Genotype patterns of the MTHFR C677T SNP. Lane $1, \mathrm{~T} / \mathrm{T}$ genotype; lanes $2 \& 4, \mathrm{C} / \mathrm{T}$ genotypes; and lanes $3 \& 5, \mathrm{C} / \mathrm{C}$ genotypes.

quency of the MS $2756 \mathrm{G}$ allele was significantly different between each pair of the three ethnic groups, being lowest in Chinese (11.0\%), moderate in Malays $(17.9 \%)$, and highest in Indians $(26.4 \%)$. The frequency of the $M S \mathrm{G} / \mathrm{G}$ genotype was also significantly different between each pair of the three ethnic groups, which was lowest in Chinese $(0.4 \%)$, moderate in Malays $(3.8 \%)$, and highest in Indians $(10.2 \%)$.

Regarding the MTHFR C677T SNP, the frequency of the 677T allele was significantly higher in Chinese than in Indians and Malays (both $p=0.000$ ), as well as the frequency of the T/T genotype, which was also significantly higher in Chinese than in Indians ( $p=$ 0.004 ) and Malays ( $p=0.017)$. Unexpectedly, there was no T/T genotype in Indians. In addition, gender bias in genotype and allele frequencies were also found in Chinese and Malays (Table 3). Specifically, the X/T genotype ( $\mathrm{C} / \mathrm{T}+\mathrm{T} / \mathrm{T}$ genotypes) was significantly less frequent in males of Chinese and Malays than in their female counterparts ( $p=0.019$ and 0.049 , respectively). The frequency of the $\mathrm{T}$ allele was also significantly lower in males than in females of Chinese $(p=$ $0.015)$, but the difference was not significant in the Malay group.

Since the possibly protective I allele of the $C B S$ 844 ins 68 polymorphism was much less frequent than the $\mathrm{N}$ allele in Singaporeans, the $M S \mathrm{~A} / \mathrm{G}$ or G/G genotype and the MTHFR T/T genotype were considered as double genetic risk factors for elevated Hcy level in this study. Four individuals $(0.7 \%)$ were carriers of such double risk factors $(M S \mathrm{~A} / \mathrm{G}+$ MTHFR $\mathrm{T} / \mathrm{T})$. Among them, 3 were Chinese $(1.1 \%)$ and 1 was Malay individual $(0.6 \%)$. No Indian individuals were carriers of the double risk factors since there was no MTHFR T/T genotype in the Indian group of this study.

\section{Discussion}

The CBS 844ins68 polymorphism was firstly reported as a novel mutation in an Italian patient with classic homocystinuria due to CBS deficiency [17]. The patient is heterozygous $(\mathrm{I} / \mathrm{N})$ for the mutation. Because the insertion (I allele) introduces a premature termination codon in the CBS mRNA, it is assumed that the truncated CBS protein is nonfunctional. However, a subsequent report [18] showed that individuals carrying the I allele of the mutation have normal-size mRNA. Later, large quantities of studies showed that the 844ins68 was commonly distributed among humans as a polymorphism. In this study, the I allele for the $C B S$ 844 ins 68 polymorphism was only present as the I/N genotype in the 556 individuals. This is expected because the I/I genotype was only found in some Caucasians with varied low frequencies ranging between 0.6 and $2.8 \%$ [19-22]. The frequency of the I allele determined here for Singaporean Chinese, 0.4\%, was the same as the frequency in Koreans [23], but was much lower than the $2.5 \%$ frequency in Southern Chinese [24], although our sample size (273 individuals) was more than twice larger than the Southern Chinese (100 individuals). Such finding indicated an intraethnic variation in terms of allelic distribution of the CBS 844ins68 polymorphism, which was also found in Indians and Italians. The I allele frequency determined in Singaporean Indians of this study $(n=127)$ was $2.0 \%$, which was only half of the frequency determined in a group of Indians $(n=138)$ from different parts of India [25]. Also, the I allele frequency is $11.0 \%$ in Northern Italians and is only $4.3 \%$ in South- 
Table 3

Distributions of genotypes and alleles of the MTHFR C677T SNP between genders

\begin{tabular}{lccccccc}
\hline \multirow{2}{*}{ Ethnic group } & Gender & \multicolumn{3}{c}{ Genotype frequency $(\mathrm{n} / \%)$} & & \multicolumn{2}{c}{ Allele frequency $(\mathrm{n} / \%)$} \\
\cline { 3 - 4 } \cline { 7 - 8 } & & $\mathrm{C} / \mathrm{C}$ & $\mathrm{C} / \mathrm{T}$ & $\mathrm{T} / \mathrm{T}$ & & $\mathrm{C}$ & $\mathrm{T}$ \\
\hline Chinese $^{\mathrm{a}}$ & Male & $61 / 61.6$ & $35 / 35.4$ & $3 / 3.0^{\mathrm{b}}$ & & $157 / 79.3$ & $41 / 20.7^{\mathrm{c}}$ \\
& Female & $76 / 46.6$ & $75 / 46.0$ & $12 / 7.4$ & & $227 / 69.6$ & $99 / 30.4$ \\
\multirow{3}{*}{ Indian } & Male & $47 / 70.1$ & $20 / 29.9$ & 0 & & $114 / 85.1$ & $20 / 14.9$ \\
& Female & $49 / 81.7$ & $11 / 18.3$ & 0 & & $109 / 90.8$ & $11 / 9.2$ \\
Malay & Male & $69 / 86.25$ & $10 / 12.5$ & $1 / 1.25^{\mathrm{d}}$ & & $148 / 92.5$ & $12 / 7.5$ \\
& Female & $56 / 73.7$ & $19 / 25$ & $1 / 1.3$ & & $131 / 86.2$ & $21 / 13.8$ \\
Total & Male & $177 / 72.0$ & $65 / 26.4$ & $4 / 1.6^{\mathrm{e}}$ & & $419 / 85.2$ & $73 / 14.8^{\mathrm{f}}$ \\
& Female & $181 / 60.5$ & $105 / 35.1$ & $13 / 4.3$ & & $467 / 78.1$ & $131 / 21.9$ \\
\hline
\end{tabular}

${ }^{a}$ Only 262 Chinese participants (out of 273) provided their gender information.

b The frequency of the T-allele carriers $(C / T+T / T)$ is significantly lower in males than in females $(p=0.019)$.

${ }^{\mathrm{c}}$ The frequency of the $\mathrm{T}$ allele is significantly lower in males than in females $(p=0.015)$.

${ }^{\mathrm{d}}$ The frequency of the T-allele carriers $(\mathrm{C} / \mathrm{T}+\mathrm{T} / \mathrm{T})$ is significantly lower in males than in females $(p=0.049)$.

eThe frequency of the $\mathrm{T}$-allele carrier $(\mathrm{C} / \mathrm{T}+\mathrm{T} / \mathrm{T})$ is significantly lower in males than in females $(p=0.005)$.

${ }^{\mathrm{f}}$ The frequency of the T allele is significantly lower in males than in females $(p=0.003)$.

ern Italians. Moreover, even among Northern Italians, this frequency ranges between 3.5 and $14 \%$, which is a four-fold difference. The frequencies among Southern Italians also vary a lot, which range between 2.7 and $7.8 \%$ [19]. Generally, among Caucasians, the frequencies of I allele range between $2.7 \%$ and $14 \%$ [19,20, 26-28], and the highest frequency determined to date is $33.3 \%$ reported in Sub-Saharan Africans [29]. Therefore, although the I allele is associated with reduced level of plasma Hcy [2,3] and subsequently lowered risk of developing atherosclerotic and/or thrombotic diseases, similar study needs to be performed to evaluate the influence of the $C B S$ 844ins68 polymorphism in particular sub-populations.

MS plays an important role in the Hcy metabolism as a key enzyme in the remethylation pathway. The $M S$ gene has been cloned, sequenced and located, and several polymorphisms have also been identified [4, 30-32]. The most prevalent polymorphism is the A2756G SNP that lead to a substitution of aspartic acid by glycine [4]. The MS 2756G allele in our Malay samples $(17.9 \%)$ was similar to the frequencies in Japanese (17.3\%) [33], Hispanics (18.8\%), and Caucasians (19.9\%) [34]. The MS 2756G allele frequency in our Chinese samples, $11.0 \%$, was similar to the frequencies reported for Chinese (8.5\%) [35], Thais (11.8\%) [36] and Koreans (13.1\%) [37]. Higher frequencies of the $M S 2756 \mathrm{G}$ allele were detected in African Americans (23.8\%) [34] and Northern Indians (24\%) [38], which were similar to that in our Indian samples $(26.4 \%)$. The $M S 2756 \mathrm{G}$ allele thus appears to be commonly but also heterogeneously distributed among the world's populations.
MTHFR also plays a vital role in the remethylation pathway of the Hcy metabolism. The C677T transition in the MTHFR coding sequence, converting an alanine (the $\mathrm{C}$ allele) into a valine residue (the $\mathrm{T}$ allele) was first reported in 1995 [7]. The T/T genotype of the SNP shows increased thermolability and about $30 \%$ of the normal MTHFR enzyme activity [7]. The reduced enzyme activity led to a hypothesis that the T/T genotype might result in elevated Hcy level in humans, which was found to be true in subsequent studies, at least in some Asian populations [6,8-11]. In this study, the MTHFR 677T allele was less common than the 677C allele in Singaporeans, which is also the case in Koreans [37], Asian Indians living in South Africa [39] or UK [40], Japanese [41], and Caucasians [40,42]. However, in some groups of Northern Chinese [42,43], the $677 \mathrm{~T}$ allele was more common than the $677 \mathrm{C}$ allele. In this study, the frequency of the $677 \mathrm{~T}$ allele was most frequent in Chinese $(27.5 \%)$, which was lower than the frequencies in other Chinese populations (30.7 to $44.6 \%$ ) reported before [44-48]. In Singaporean Indians, the frequency of the $677 \mathrm{~T}$ allele was $12.2 \%$, being similar to the frequencies in Asian Indians living in South Africa (11\%) [39] and UK (15.0\%) [40], and to the frequency in Malays (10.6\%) of this study.

As for the MTHFR C677T SNP, we even found that females were more likely to be carriers of $677 \mathrm{~T}$ allele than their male counterparts in Chinese and Malays, because the combined frequencies of $\mathrm{C} / \mathrm{T}$ and $\mathrm{T} / \mathrm{T}$ genotypes were significantly higher in females of Chinese $(p=0.019)$ and Malays $(p=0.049)$. As such, the frequencies of $\mathrm{T}$ allele were significantly higher in females of Chinese $(p=0.015)$. While in the Malay 
group, the difference was not significant. However, further analysis showed that there were no gender bias on the frequency of T/T genotype in Chinese and Malays. This result was consistent with the recent finding that genotype frequencies were similar between males and females [49], but was in contrast to a study reporting that two-thirds of newborn infants with the T/T genotype were males [50]. There is no suggested explanation for such conflicting results yet. Nonetheless, different influence of the MTHFR C677T SNP on males and females were found [51-53] regarding to diseases, suggesting a requirement of further studies on the SNP and, for example, sex-differentiated hormones.

The complicated distributions of the three polymorphisms stated above, although difficult to explain, could be possibly due to the differences in genetic drift or selection against a particular allele or genotype among populations. For example, mutations in these genes in some ethnic groups are so deleterious that they are lethal to the fetus and are thus not propagated or resulted in rare genotypes. Take the MTHFR C677T as an example. The frequency of the T/T genotype was $13.2 \%$ in Europe [54], whereas in our Indian samples, there was no T/T genotype at all. Even among other Indian populations, the frequency of the T/T genotype was lower than $3 \%[39,40]$. It has been found that the MTHFR T/T genotype in women was associated with recurrent early pregnancy loss [55] and that the prevalence of the T/T genotype was increased following supplementation of pregnant women with multivitamins [56]. Compared to Europeans, Indians consumed significantly less B vitamin supplements [57]. Moreover, the majority of Indians are vegetarians due to cultural and religious reasons, and a strict vegetarian diet has been associated with an increased risk of vitamin B deficiency, especially B12 [58-60]. Therefore, it is reasonable that the frequency of $M T H F R$ T/T genotype was significantly different between ethnic groups. Besides the possible genetic-environmental selection, differences in sample size or bias resulting from sample selection of the populations studied may play a role. For instance, it was found that the prevalence of the MS 2756G allele was significantly higher in elders than in younger individuals [61]. Therefore, average age of the participants in a study should be considered. In a word, in association studies between these three polymorphisms and diseases, many factors, i.e., genetic background, sample size, sample characteristics, and gender ratio, should be counted in with care.

Based on the three polymorphisms determined here, the risk for elevated Hcy level in Singaporeans was about $0.7 \%$ (4 individuals carrying both $M S$ A/G genotype and MTHFR T/T genotype out of 556 participants). When the ethnicity of the participants was considered, the result suggested that Singaporean Chinese were at higher risk for developing diseases related to higher Hcy level than Malays, because the combined frequency of the double risk factors was $1.1 \%$ in Chinese and $0.6 \%$ in Malays. Simply based on these three polymorphisms, it is difficult to compare the risk for elevated Hcy level between Indians and the other two ethnic groups. On one hand, Indians had much higher frequency of $M S \mathrm{~A} / \mathrm{G}+\mathrm{G} / \mathrm{G}$ genotypes that lead to higher Hcy level. On the other hand, Indians did not have MTHFR T/T genotype but had higher CBS 844ins68 I allele that related to lower Hcy concentrations [2,3]. Therefore, in order to better understand the relations of the three polymorphisms and plasma Hcy levels, further studies with blood samples from participants are required, although a previous general study found no significant differences of plasma total Hcy level among Singaporean Chinese, Indians, and Malays [62]. In this sense, it was a major limit that we can only get buccal cell samples instead of blood samples from the participants.

Among Asian populations, besides these three gene polymorphisms, human Hcy level was found to be significantly affected by many other non-genetic factors, such as gender, age, and plasma/serum levels of folate and vitamin B12 [57,63-65]. As such, to fully understand the gene polymorphisms involved in Hcy metabolism and Hcy level, all the aforementioned factors need to be considered and measured in later studies.

In summary, this report is the first to provide allele frequencies in randomly selected Singaporeans for the polymorphisms in three genes involved in the metabolism of Hcy. Although roughly, to screen the individuals that are at increased risk for elevated Hcy level (such as the genotypes of the three polymorphisms studied here) might provide an opportunity for public prevention and therapeutic intervention of diseases related to high Hcy level. This is possible because the human plasma total Hcy is inversely related with plasma and/or serum levels of folate and vitamin B12 [64-67] and sufficient intake of folate and vitamin B supplements can compensate the harmful high Hcy level [57, 63,65]. Among Singaporeans, the screening of risk markers for higher Hcy level seems more important in Indians, the majority of whom adhere to a vegetarian diet for cultural and religious reasons, because a strict vegetarian diet has been associated with an increased 
risk of vitamin B12 deficiency [58-60]. Nonetheless, it should be noted that the genetic risk for high-Hcy related diseases could either be greater or lower than that measured by these three genes. Therefore, in order to be more convincing, it is undoubted that largescale prospective population studies are in need to further elucidate the relationships between these polymorphisms, other polymorphisms, and the susceptibility to high-Hcy related diseases, such as CAD, CVD, venous thromboembolism, etc., in Singaporeans.

\section{Acknowledgements}

The authors wish to thank the National Institute of Education in supporting this research, by providing the research grant RP19/00GYY and the graduate student scholarship.

\section{References}

[1] N.M.J. van der Put, E.F. van der Molen, L.A.J. Kluijtmans, S.G. Heil, J.M.F. Trijbels, T.K.A.B. Eskes, D. Van OppenraaijEmmerzaal, R. Banerjee and H.J. Blom, Sequence analysis of the coding region of human methionine synthase: relevance to hyperhomocysteinaemia in neural-tube defects and vascular disease, QJM: An International Journal of Medicine $\mathbf{9 0}$ (1997), 511-517.

[2] M.Y. Tsai, M. Bignell, F. Yang, B.G. Welge, K.J. Graham and N.Q. Hanson, Polygenic influence on plasma homocysteine: association of two prevalent mutations, the 844ins68 of cystathionine $\beta$-synthase and $\mathrm{A}_{2756} \mathrm{G}$ of methionine synthase, with lowered plasma homocysteine levels, Atherosclerosis 149 (2000), 131-137.

[3] M.Y. Tsai, F. Yang, M. Bignell, O. Aras and N.Q. Hanson, Relation between plasma homocysteine concentration, the 844ins68 variant of the cystathionine $\beta$-synthase gene, and pyridoxal-5' -phosphate concentration, Molecular Genetics and Metabolism 67 (1999), 352-356.

[4] D. Leclerc, E. Campeau, P. Goyette, C.E. Adjalla, B. Christensen, M. Ross, P. Eydoux, D.S. Rosenblatt, R. Rozen and R.A. Gravel, Human methionine synthase: cDNA cloning and identification of mutations in patients of the $c b l G$ complementation group of folate/cobalamin disorders, Human Molecular Genetics 5 (1996), 1867-1874.

[5] T.F. Ashavaid, K.K. Shalia, A.A. Kondkar, S.P. Todur, K.G. Nair and S.R. Nair, Gene polymorphism and coronary risk factors in Indian population, Clinical Chemistry and Laboratory Medcine 40 (2002), 975-985.

[6] O.J. Kim, S.P. Hong, J.Y. Ahn, S.H. Hong, T.S. Hwang, S.O. Kim, W. Yoo, D. Oh and N.K. Kim, Influence of combined methionine synthase (MTR 2756A > G) and methylenetetrahydrofolate reductase (MTHFR $677 \mathrm{C}>\mathrm{T}$ ) polymorphisms to plasma homocysteine levels in Korean patients with ischemic stroke, Yonsei Medical Journal 48 (2007), 201-209.

[7] P. Frosst, H.J. Blom, R. Milos, P. Goyette, C.A. Sheppard, R.G. Matthews, G.J.H. Boers, M. den Heijer, L.A.J. Kluijtmans, L.P. van den Heuvel and R. Rozen, A candidate genetic risk factor for vascular disease: a common mutation in methylenetetrahydrofolate reductase, Nature Genetics $\mathbf{1 0}$ (1995), 111-113.

[8] M. Kawashiri, K. Kajinami, A. Nohara, K. Yagi, A. Inazu, J. Koizumi and H. Mabuchi, Effect of common methylenetetrahydrofolate reductase gene mutation on coronary artery diseases in familial hypercholesterolemia, The American Journal of Cardiology 86 (2000), 840-845.

[9] T. Ou, K. Yamakawa-Kobayashi, T. Arinami, H. Amemiya, H. Fujiwara, K. Kawata, M. Saito, S. Kikuchi, Y. Noguchi, Y. Sugishita and H. Hamaguchi, Methylenetetrahydrofolate reductase and apolipoprotein E polymorphisms are independent risk factors for coronary heart disease in Japanese: a case-control study, Atherosclerosis 137 (1998), 23-28.

[10] C.H. Ho, The influence of age, sex, vitamin $B_{12}$, folate levels and methylenetetrahydrofolate reductase C677T genetic mutations on plasma homocysteine in the Chinese population, Haematologica 85 (2000), 1051-1054.

[11] J.Z. Sun, Y.C. Xu, Y.L. Zhu and H.Y. Lu, Genetic polymorphism of methylenetetrahydrofolate reductase as a risk factor for diabetic nephropathy in Chinese type 2 diabetic patients, Diabetes Research and Clinical Practice 64 (2004), 185-190.

[12] V.R. Bhagwat, A.S. Yadav and I.M. Rathod, Homocysteine, lipid indices and antioxidants in patients with ischaemic heart disease from Maharashtra, India, Singapore Medical Journal 50 (2009), 418-424.

[13] G. Zhang and C. Dai, Correlation analysis between plasma homocysteine level and polymorphism of homocysteine metabolism related enzymes in ischemic cerebrovascular or cardiovascular diseases, Zhonghua Хие Yе Хие Za Zhi 23 (2002), 126-129.

[14] C.L. Chao, H.H. Tsai, C.M. Lee, S.M. Hsu, J.T. Kao, K.L. Chien, F.C. Sung and Y.T. Lee, The graded effect of hyperhomocysteinemia on the severity and extent of coronary arherosclerosis, Atherosclerosis 147 (1999), 379-380.

[15] C.H. Ho, B.I.T. Kuo, C.W. Kong, W.K. Chau, H.C. Hsu, J.P. Gau and Y.B. Yu, Influence of methylenetetrahydrofolate reductase (MTHFR) C677T polymorphism, B vitamins and other factors on plasma homocysteine and risk of thromboembolic disease in Chinese, Journal of the Chinese Medical Association 68 (2005), 560-565.

[16] T.S. Hsu, L.A. Hsu, C.J. Chang, C.F. Sun, Y.L. Ko, C.T. Kuo, C.W. Chiang and Y.S. Lee, Importance of hyperhomocysteinemia as a risk factor for venous thromboembolism in a Taiwanese population. A case-control study, Thrombosis Research 102 (2001), 387-395.

[17] G. Sebastio, M.P. Sperandeo, M. Panico, R. de Franchis, J.P. Krans and G. Andria, The molecular basis of homocystinuria due to cystathionine $\beta$-synthase deficiency in Italian families, and report of four novel mutations, American Journal of $\mathrm{Hu}$ man Genetics 56 (1995), 1324-1333.

[18] M.Y. Tsai, M. Bignell, K. Schiwichtenberg and I.V. Hanson, High prevalence of a mutation in the cystathionine $\beta$-synthase gene, American Journal of Human Genetics 59 (1996), 12621267.

[19] B. Giusti, O. Camacho-Vanegas, M. Attanasio, P. Comeglio, A.M. Gori, T. Brunelli, D. Prisco, G.F. Gensini, R. Abbate and G. Pepe, Microheterogeneity in the distribution of the 844 ins 68 in the cystathionine $\beta$-synthase gene in Italy, Thrombosis Research 94 (1999), 249-254.

[20] Y.J. Kim, R.A. Williamson, J.C. Murray, J. Andrews, J.J. Pietscher, P.J. Peraud and D.C. Merrill, Genetic susceptibility to preeclampsia: roles of cytosine-to-thymine substitution at nucleotide 677 of the gene for methylenetetrahydrofolate reductase, 68-base pair insertion at nucleotide 844 of the gene 
for cystathionine $\beta$-synthase, and factor $\mathrm{V}$ leiden mutation, American Journal of Obstetrics and Gynecology 184 (2001), 1211-1217.

[21] L.A.J. Kluijtmans, G.H.J. Boers, F.J.M. Trijbels, H.M.A. van Lith-Zanders, L.P.W.J. van den Heuvel and H.J. Blom, A common 844ins68 insertion variant in the cystathionine $\beta$-synthase gene, Biochemical and Molecular Medicine 62 (1997), 23-25.

[22] C. Konrad, G.A. Muller, C. Langer, G. Kuhlenbaumer, K. Berger, D.G. Nabavi, R. Dziewas, F. Stogbaner, E.B. Ringelstein and R. Junker, Plasma homocysteine, MTHFR C677T, CBS 844ins68, and MTHFD1 G1958A polymorphisms in spontaneous cervical artery dissections, Journal of Neurology 251 (2004), 1242-1248.

[23] S.H. Hong, J. Song and J.Q Kim, Genetic variation of the methylenetetrahydrofolate reductase and cystathionine $\beta$ synthase genes in Korean patients with coronary artery disease and a new polymorphism in intron 7, Molecular and Cellular Probes 15 (2001), 119-123.

[24] G.S. Zhang and C.W. Dai, Gene polymorphisms of homocysteine metabolism-related enzymes in Chinese patients with occlusive coronary artery or cerebral vascular disease, Thrombosis Research 104 (2001), 187-195.

[25] S. Dutta, S. Sinha, A. Chattopadhyay, P.K. Gangopadhyay, J. Mukhopadhyay, M. Singh and K. Mukhopadhyay, Cystathionine $\beta$-synthase T833C/844INS68 polymorphism: a familybased study on mentally retarded children, Behavioral and Brain Functions 1 (2005), 25-30.

[26] V. De Stefano, V. Dekou, V. Nicaud, J.F. Chasse, J. London, D. Stansbie, S.E. Humphries and V. Gudnason, Linkage disequilibrium at the cystathionine $\beta$ synthase (CBS) locus and the association between genetic variation at the CBS locus and plasma levels of homocysteine, Annals of Human Genetics 62 (1998), 481-490.

[27] M. Orendac, B. Muskova, E. Richterova, J. Zvarova, M. Stefek, E. Zaykova, J.P. Kraus, J. Stribrny, J. Hyanek and V. Kozich, Is the common 844ins 68 polymorphism in the systathionine $\beta$-synthase gene associated with atherosclerosis? Journal of Inherited Metabolic Disease 22 (1999), 674-675.

[28] M.C. Speer, J. Nye, D. McLone, G. Worley, E.C. Melvin, K.D. Viles, A. Franklin, C. Drake, J. Mackey, T.M. George and NTD Collaborative Group, Possible interaction of genotypes at cystathionine $\beta$-synthase and methylenetetrahydrofolate reductase (MTHFR) in neural tube effects, Clinical Genetics $\mathbf{5 6}$ (1999), 142-144.

[29] G. Pepe, O.C. Vanegas, O. Rickards, B. Giusti, P. Comeglio, T. Brunelli, R. Marcucci, D. Prisco, G.F. Gensini and R. Abbate, World distribution of the T833C/844INS68 CBS in cis double mutation: a reliable anthropological marker, Human Genetics 104 (1999), 126-129.

[30] L.H. Chen, M.L. Lin, H.Y. Hwang, L.S. Chen, J. Korenberg and B. Shane, Human methionine synthase: cDNA cloning, gene location and expression, Journal of Biological Chemistry 273 (1997), 3628-3634.

[31] S. Gulati, P. Baker, Y.N. Li, B. Fower, W. Kruger, L.C. Brody and R. Banerjee, Deffects in human methionine synthase in cblG patients, Human Molecular Genetics 5 (1996), 18591865.

[32] Y.N. Li, S. Gulati, P.J. Baker, L.C. Brody, R. Banerjee and W.E. Kruger, Cloning, mapping and RNA analysis of the human methionine synthase gene, Human Molecular Genetics 5 (1996), 1851-1858.

[33] H. Morita, H. Kurihara, T. Sugiyama, C. Hamada, Y. Kurihara, T. Shindo, Y. Oh-hashi and Y. Yazaki, Polymorphism of the methionine synthase gene. Association with homocysteine metabolism and late-onset vascular diseases in the Japanese population, Arteriosclerosis, Thrombosis, and Vascular Biology 19 (1999), 298-302.

[34] J.M. Conroy, G. Trivedi, T. Sovd and M. Caggana, The allele frequency of mutations in four genes that confer enhanced susceptibility to venous thromboembolism in and unselected group of New York state newborns, Thrombosis Research 99 (2000), 317-324.

[35] H.L. Zhao, X.Q. Li, Z.X. Zhang, X.H. Bi, B. Wang and J.W. Zhang, Association analysis of methionine synthase gene 2756 A $>$ G polymorphism and Alzheimer disease in a Chinese population, Brain Research 1204 (2008), 118-122.

[36] N. Sirachainan, S. Wongruangsri, S. Kajanachumpol, S. Pakakasama, A. Visudtibhan, I. Nuchprayoon, A. Lusawat, S. Phudhicharoenrat, S. Shuangshoti and S. Hongeng, Folate pathway genetic polymorphisms and susceptibility of central nervous system tumors in Thai children, Cancer Detection and Prevention 32 (2008), 72-78.

[37] H.N. Kim, Y.K. Kim, I.K. Lee, J.J. Lee, D.H. Yang, K.S. Park, J.S. Choi, M.R. Park, D.Y. Jo and H.J. Kim, Polymorphisms involved in the folate metabolizing pathway and risk of multiple myeloma, American Journal of Hematology 82 (2007), 798-801.

[38] M. Shekari, R.C. Sobti, D.M.K. Tamandani and V. Suri, Impact of methylenetetrahydrofolate reductase (MTHFR) codon (677) and methionine synthase (MS) codon (2756) on risk of cervical carcinogenesis in North Indian population, Archives of Gynecology and Obstetrics 278 (2008), 517-524.

[39] N. Ranjith, R.J. Pegoraro and L. Rom, Risk factors and methylenetetrahydrofolate reductase gene polymorphisms in a young South African Indian-based population with acute myocardial infarction, Cardiovascular Journal of South Africa 14 (2003), 127-132

[40] J.C. Chambers, H. Ireland, E. Thompson, P. Reilly, O.A. Obeid, H. Refsum, P. Ueland, D.A. Lane and J.S. Kooner, Methylenetetrahydrofolate reductase $677 C \diamond T$ mutation and coronary heart disease risk in UK Indian Asians, Arteriosclerosis, Thrombosis, and Vascular Biology 20 (2000), 24482452.

[41] H. Morita, H. Kurihara, S. Tsubaki, T. Sugiyama, C. Hamada, Y. Kurihara, T. Shindo, Y. Oh-hashi, K. Kitamura and Y. Yazaki, Methylenetetrahydrofolate reductase gene polymorphism and ischemic stroke in Japanese, Arteriosclerosis, Thrombosis, and Vascular Biology 18 (1998), 1465-1469.

[42] J.H. Zhang, R.B. Zotz, Y. Li, R. Wang, S. Kiel, W.A. Schulz, D. Wen, Z.F. Chen, L.W. Zhang, S.J. Wang, H.E. Gabbert and M. Sarbia, Methylenetetrahydrofolate reductase C677T polymorphism and predisposition towards esophageal squamous cell carcinoma in a German Caucasian and a northern Chinese population, Journal of Cancer Research and Clinical Oncology 130 (2004), 574-580.

[43] R.Z. Stolzenberg-Solomon, Y.L. Qiao, C.C. Abnet, D.L. Ratnasinghe, S.M. Dawsey, Z.W. Dong, P.R. Taylor and S.D. Mark, Esophageal and gastric cardia cancer risk and folateand vitamin $\mathrm{B}_{12}$-related polymorphisms in Linxian, China, Cancer Epidemiology, Biomarkers and Prevention 12 (2003), 1222-1226.

[44] X.P. Miao, D.Y. Xing, W. Tan, J. Qi, W.F. Lu and D.X. Lin, Susceptibility to gastric cardia adenocarcinoma and genetic polymorphisms in methylenetetrahydrofolate reductase in an at-risk Chinese population, Cancer Epidemiology, Biomarkers and Prevention 11 (2002), 1454-1458.

[45] L.N. Mu, W. Cao, Z.F. Zhang, L. Cai, Q.W. Jiang, N.C. You, B.Y. Goldstein, G.R. Wei, C.W. Chen, Q.Y. Lu, X.F. Zhou, 
B.G. Ding, J. Chang and S.Z. Yu, Methylenetetrahydrofolate reductase (MTHFR) C677T and A1298C polymorphisms and the risk of primary Hepatocellular Carcinoma (HCC) in a Chinese population, Cancer Causes and Control 18 (2007), 665-675.

[46] H.B. Shen, Y.C. Xu, Y.X. Zheng, Y. Qian, R.B. Yu, Y. Qin, X.R. Wang, M.R. Spitz and Q.Y. Wei, Polymorphisms of 5,10methylenetetrahydrofolate reductase and risk of gastric cancer in a Chinese population: a case-control study, International Journal of Cancer 95 (2001), 332-336.

[47] C.Y. Song, D.Y. Xing, W. Tan, Q.Y. Wei and D.X. Lin, Methylenetetrahydrofolate reductase polymorphisms increase risk of esophageal squamous cell carcinoma in a Chinese population, Cancer Research 61 (2001), 3272-3275.

[48] Y.Z. Zheng, J. Tong, X.P. Do, X.Q. Pu and B.T. Zhou, Prevalence of methylenetetrahydrofolate reductase C677T and its association with arterial and venous thrombosis in the Chinese population, British Journal of Haematology 109 (2000), 870-874.

[49] C. Papoutsakis, N. Yiannakouris, Y. Manios, E. Papaconstantinou, F. Magkos, K.H. Schulpis, A. Zampelas and A.L. Matalas, The effect of MTHFR (C677T) genotype on plasma homocysteine concentrations in healthy children is influenced by gender, European Journal of Clinical Nutrition 60 (2006), $155-162$.

[50] R. Rozen, F.C. Fraser and G. Shaw, Decreased proportion of female newborn infants homozygous for the $677 \mathrm{C} \diamond \mathrm{T}$ mutation in methylenetetrahydrofolate reductase, American Journal of Medical Genetics 83 (1999), 142-143.

[51] H. Reddy and K. Jamil, Polymorphisms in the MTHFR gene and their possible association with susceptibility to childhood acute lymphocytic leukemia in an Indian population, Leukemia and Lymphoma 47 (2006), 1333-1339.

[52] J.R. Ruiz, R. Sola, M. Gonzalez-Gross, F.B. Ortega, G. Vicente-Rodriguez, M. Garcia-Fuentes, A. Gutierrez, M. Sjostrom, K. Pietrzik and M.J. Castillo, Cardiovascular fitness is negatively associated with homocysteine levels in female adolescents, Archives of Pediatrics and Adolescent Medicine 161 (2007), 166-171

[53] W.L. Zhu, Y. Li, L.Y. Yan, J.J. Dao and S.Q. Li, Maternal and offspring MTHFR gene $C 677 T$ polymorphism as predictors of congenital atrial septal defect and patent ductus arteriosus, Molecular Human Reproduction 12 (2006), 51-54.

[54] L.D. Botto and Q.H. Yang, 5, 10-Methylenetetrahydrofolate reductase gene variants and congenital anomalies: a HuGE review, American Journal of Epidemiology 151 (2000), 862 877.

[55] W.L. Nelen, E.A. Steegers, T.K. Eskes and H.J. Blom, Genetic risk factor for unexplained recurrent early pregnancy loss, Lancet 350 (1997), 861.

[56] E. Munoz-Moran, J.L. Dieguez-Lucena, N. Fernandez-Arcas, S. Peran-Mesa and A. Reyes-Engel, Genetic selection and folate intake during pregnancy, Lancet 352 (1998), 1120-1121.
[57] L.E. Kelemen, S.S. Anand, R.A. Hegele, M.J. Stampfer, B. Rosner, W.C. Willett, P.A. Montague, E. Lonn, V. Vuksan, K.K. Teo, S. Devanesen and S. Yusuf, Associations of plasma homocysteine and the methylenetetrahydrofolate reductase C677T polymorphism with carotid intima media thickness among South Asian, Chinese and European Canadians, Atherosclerosis 176 (2004), 361-370.

[58] V. Herbert, Staging vitamin B-12 (cobalamin) status in vegetarians, American Journal of Clinical Nutrition 59(suppl) (1994), 1213S-1222S.

[59] T.A. Sanders, The nutritional adequacy of plant-based diet, Proceedings of the Nutrition Society 58 (1999), 265-269.

[60] H. Refsum, C.S. Yajnik, M. Gadkari, J. Schneede, S.E. Vollset, L. Orning, A.B. Guttormsen, A. Joglekar, M.G. Sayyad, A. Ulvik and P.M. Ueland, Hyperhomocysteinemia and elevated methylmalonic acid indicate a high prevalence of cobalamin deficiency in Asian Indians, American Journal of Clinical Nutrition 74 (2001), 233-241.

[61] M. Linnebank, K. Fliessbach, H. Kolsch, M. Rietschel and $\mathrm{U}$. Wullner, The methionine synthase polymorphism c. $2756 \mathrm{~A} \rightarrow \mathrm{G}(\mathrm{D} 919 \mathrm{G})$ is relevant for disease-free longevity, International Journal of Molecular Medicine 16 (2005), 759761.

[62] K. Hughes and C.N. Ong, Homocysteine, folate, vitamin B12, and cardiovascular risk in Indians, Malays, and Chinese in Singapore, Journal of Epidemiology and Community Health 54 (2000), 31-34.

[63] G.Y.H. Ho, J.W. Eikelboom, G.J. Hankey, C.R. Wong, S.L. Tan, J.B.C. Chan and C.P.L.H. Chen, Methylenetetrahydrofolate reductase polymorphisms and homocysteine-lowering effect of vitamin therapy in Singaporean stroke patients, Stroke 37 (2006), 456-460.

[64] J.S. Lin, M.C. Shen, W.C. Cheng, W. Tsay, Y.C. Wang, B.B. Lin and M.H. Hung, Age, sex and vitamin status affect plasma level of homocysteine, but hyperhomocysteinaemia is possibly not an important risk factor for venous thrombophilia in Taiwanese Chinese, British Journal of Haematology 117 (2002), 159-163.

[65] S.M. Saw, J.M. Yuan, C.N. Ong, K. Arakawa, H.P. Lee, G.A. Coetzee and M.C. Yu, Genetic, dietary, and other lifestyle determinants of plasma homocysteine concentrations in middleaged and older Chinese men and women in Singapore, American Journal of Clinical Nutrition 73 (2001), 232-239.

[66] J.C. Chambers, O.A. Obeid, H. Refsum, P. Ueland, D. Hackett, J. Hooper, R.M. Turner, S.G. Thompson and J.S. Kooner, Plasma homocysteine concentrations and risk of coronary heart disease in UK Indian Asian and European men, The Lancet 355 (2000), 523-527.

[67] L. Feng, T.P. Ng, L. Chuah, M. Niti and E.H. Kua, Homocysteine, folate, and vitamin B-12 and cognitive performance in older Chinese adults: findings from the Singapore Longitudinal Ageing Study, American Journal of Clinical Nutrition $\mathbf{8 4}$ (2006), 1506-1512. 


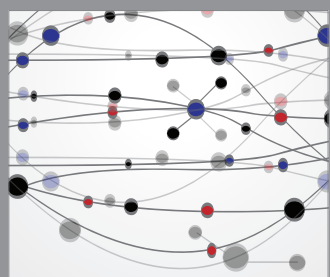

The Scientific World Journal
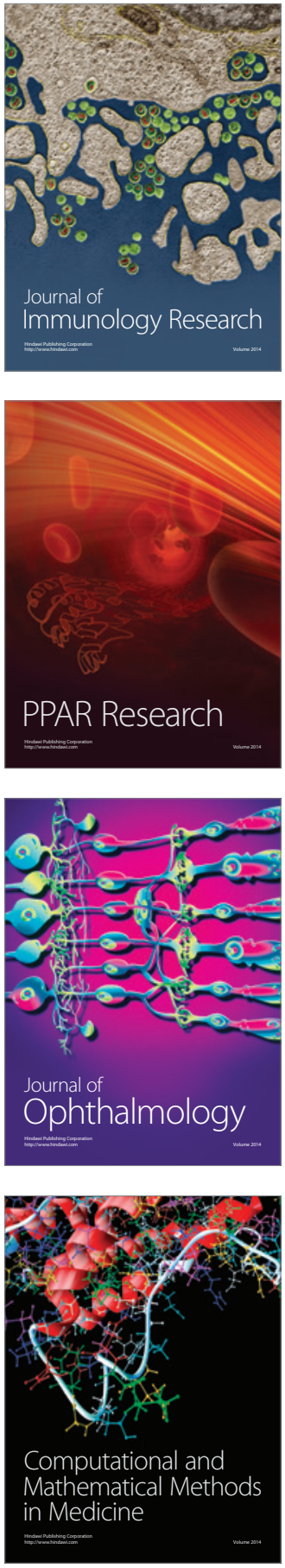

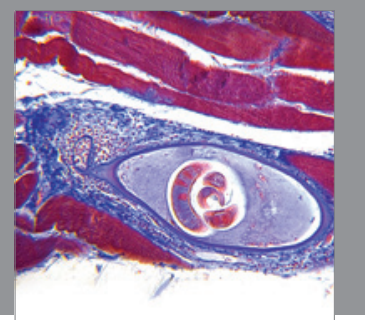

Gastroenterology

Research and Practice
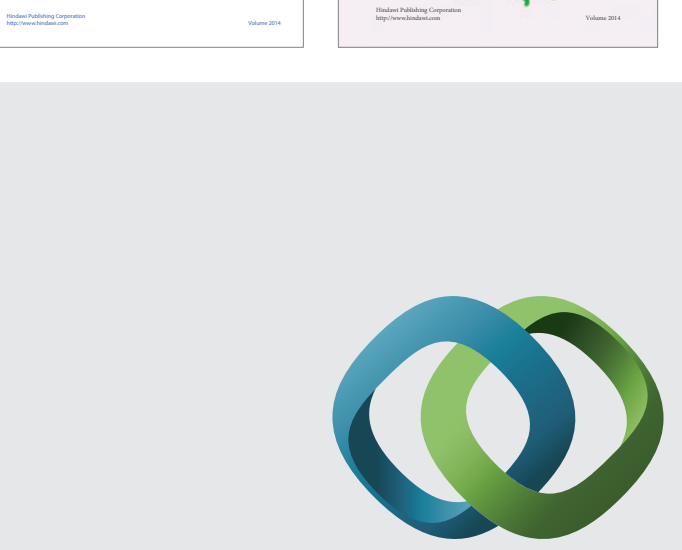

\section{Hindawi}

Submit your manuscripts at

http://www.hindawi.com
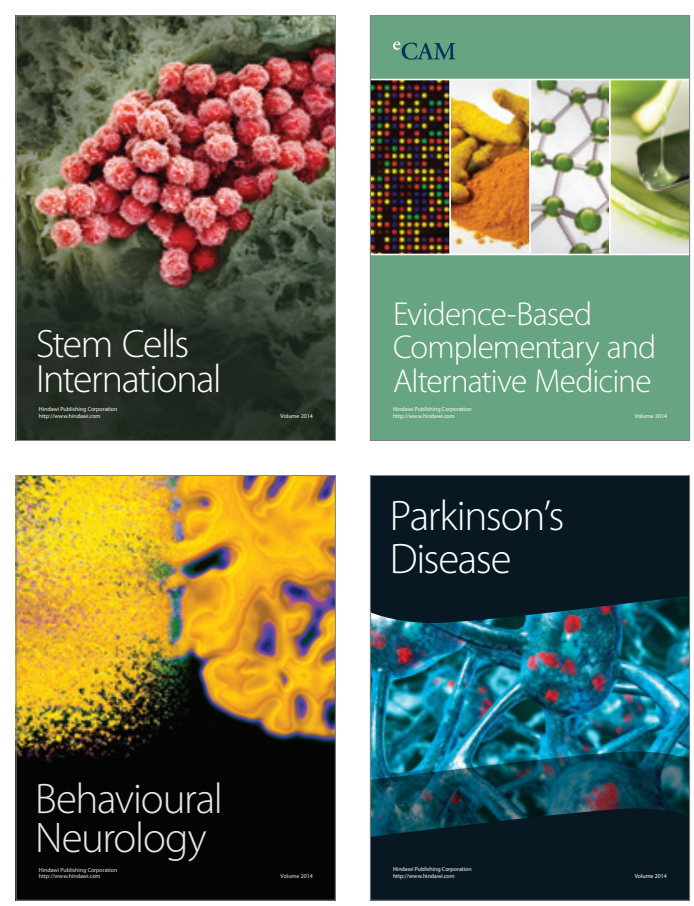

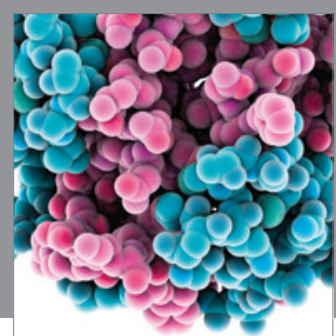

Journal of
Diabetes Research

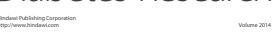

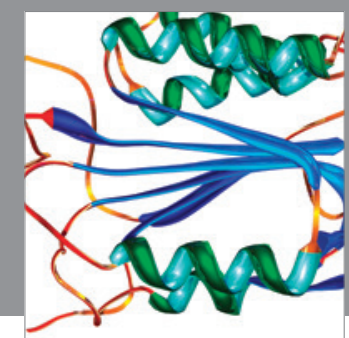

Disease Markers
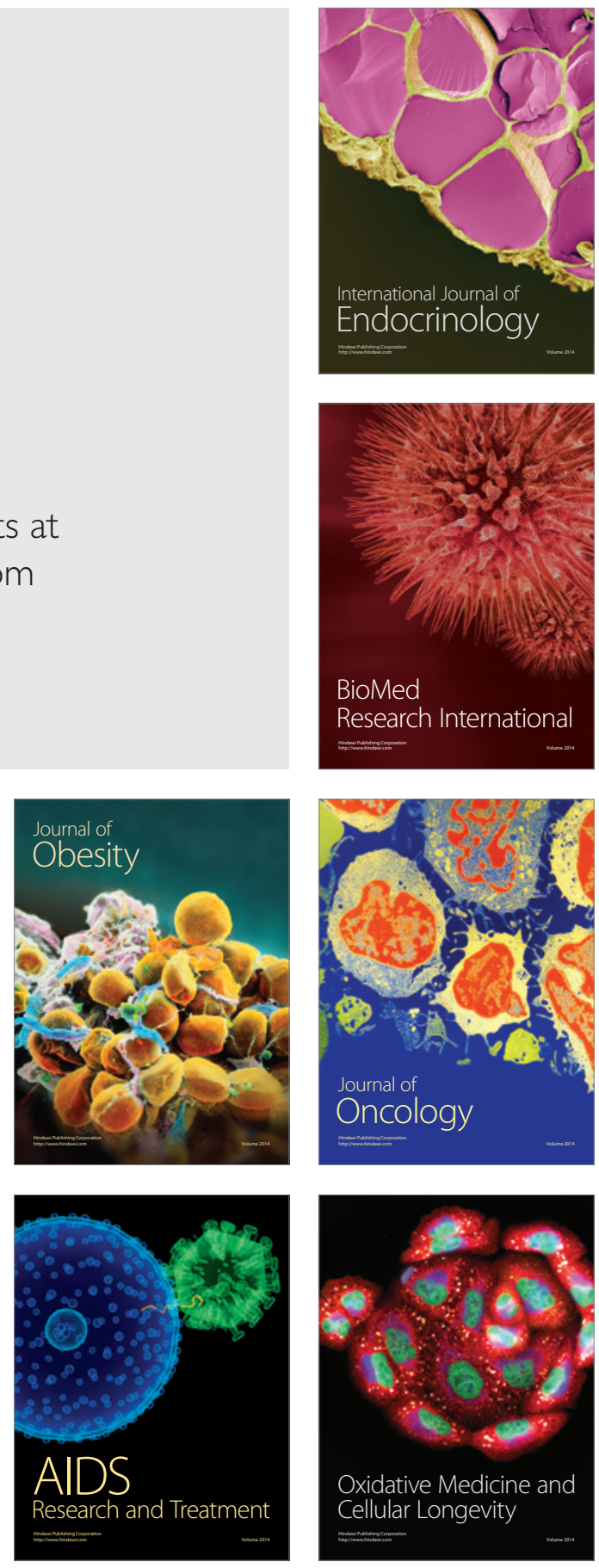